\title{
CROSS-CULTURAL LITERATURE ANDCULTURAL REPRODUCTION: THE CASE OF THE KOREAN AUTOBIOGRAPHY HANJUNGNOK
}

\author{
Kyu Hyun PARK, PhD Candidate \\ Northumbria University \\ English Language and Linguistics, Department of Humanities, \\ Newcastle upon Tyne, NE1 8ST, \\ England, United Kingdom \\ kyu.park@northumbria.ac.uk
}

\begin{abstract}
This paper is an investigation how cultural perception could be embedded in language and literature and how this helps different analyses on a same historical event. The article includes the comparison between a work of classical Korean literature, Hanjungnok (한중록), and an Englishtranslated version of it, The Memoirs of Lady Hyekyong, translated by KimHaboush, and a work of a British novel, The Red Queen, written by Margaret Drabble. The comparison is to explore the language use regarding a perception of family relations and of gender in each version of writing. This paper concludes that authors' and audience's language and cultural background would influence on perceiving and analysing literature and its context so that each interpretation could be differentiated, even with the actual historical event.
\end{abstract}


Key words: Korean Literature, Hyegyeonggung Hongssi, Margaret Drabble, Universal Literature, Hanjungnok

비교문화 문학과 문화적 재생산: 한국의 자서전 한중록을 바탕으로

논문초록: 이 연구는 언어와 문학 속에 문화적 인식이 담겨 있는 지와 이러한 문화적 인식이 하나의 역사적 사건에 대해서 어떻게 다른 해석을 하는 지를 살펴본다. 이를 위해, 궁중소설인 한중록과, 킴-하부쉬가 영어로 번역한 한중록의 번역본, 마지막으로, 소설가 마가렛 드래블이 집필한 소설 '더 레드 퀸 (붉은 왕세자빈)'에서 사용된 언어들을 비교한다. 특히, 가족과 젠더에 관한 인식에 대해서 조사한다. 이 요소들을 통해서 작가와 독자들의 언어적, 문화적 배경에 따라서 문학을 인식하고 적용하는 것은 다르며, 또한 사실을 기반으로 한 역사적 상황에 대해서도 다른 해석이 가능할 수 있다는 것을 밝힌다.

주제어: 한국 문학, 혜경궁 홍씨, 마가렛 드래블, 한중록, 보편(적) 문학

\section{LITERATURA MIĘDZYKULTUROWA A KULTUROWE ODTWARZANIE: PRZYPADEK HANJUNGNOK - KOREAŃSKIEJ AUTOBIOGRAFII}

Abstrakt: Niniejszy artykuł skupia się na zjawisku percepcji kulturowej zanurzonej w literaturze i języku a także na tym, w jakim stopniu jest ono przydatna $\mathrm{w}$ analizach zjawisk historycznych. Tekst zawiera porównanie klasycznego dzieła koreańskiego, Hanjungnok (한중록) oraz jego angielskiego przekładu Kim Haboush - The Memoirs of Lady Hyekyŏng i powieści Margaret Drabble The Red Queen. Zestawienie to pozwala na porównanie języka wykorzystanego $\mathrm{w}$ tych powieściach $\mathrm{w}$ aspektach relacji rodzinnych i rodzaju każdej z tych pozycji. Artykuł prowadzi do wniosku, że tło kulturowe oraz język autora i odbiorcy wpływają na percepcję $i$ analizę literatury z jej kontekstem. Każda z tych interpretacji różni się, mimo, że odnoszą się do tych samym faktów historycznych.

Słowa-klucze: literatura koreańska, Hyegyeonggung Hongssi, Margaret Drabble, literatura uniwersalna, Hanjungnok 


\section{Introduction}

Margaret Drabble is a famous British feminist author who has been called a contemporary Bronte sister. In 2004, she published a novel entitled The Red Queen which has been listed as one of the '1000 Books You Must Read Before You Die' (The Guardian 2011). It is interesting that this novel has attracted readers to its story, which tells of a far-east Asian country's history and traditions, but it is doubtful whether readers regard the story as history or as a novel. This is significant because it does actually illustrate real historical events in the eighteenth centuries in Korea under the Joseon dynasty. Even though a novel is an artificially created form of literature, it can still possibly create images of real events and real characters. Drabble's book was inspired by The Memoirs of Lady Hyekyong, translated into English by Kim-Haboush. The novel is divided into two parts: past and present settings. The past is principally narrated by the ghost of Lady Hyekyŏng, who recalls her life and tells her story to readers. The plot is that Lady Hyekyŏng talks about her life after she has observed the changing world from her afterlife viewpoint. What makes this possible is that Lady Hyekyŏng as a ghost has knowledge of the history and philosophy of Western institutions and she explains Korean historical events from the Western perspective using many examples drawn from Freudian psychoanalysis and historical events in Europe.

Hyegyeonggung Hongssi (1735-1815), also known as Lady Hyekyŏng or Lady Hong (in order to avoid confusion, this paper will indicate her name as Hyegyeonggung Hongssi in the official Revised Romanization of South Korea), was the wife of Jangjo (莊祖, 17351762). Jangjo is well-known as Sado Seja, the crown prince and son of Yeongjo (英祖, 1694-1776), the twenty-first king of Korea, who reigned from 1724 to 1776 and was of the Joseon dynasty (KimHaboush 2011: 352). Sado Seja is remembered as one of the most shockingly tragic royal family members and crown princes because he died in a rice chest after his father, King Yeongjo, had ordered him to be captured and locked in the chest in order to prevent him from escaping. Sado Seja struggled inside the rice chest for a week and eventually died there. This is called the Imo Incident. The major reason for it is believed to be that King Yeongjo was upset by Sado Seja's unacceptable behavior as a crown prince. It has been stated that 
Sado Seja had a mental disease, probably an obsession, which drove him to kill innocent people. Hyegyeonggung Hongssi wrote her autobiography from a family-centered perspective. The autobiography is entitled Hanjungnok and it describes her entire life from her childhood to her marriage and life in a palace. She started with her childhood and stories about her family and then went on to talk about her life after being selected to become a crown princess and moving into the palace to become part of the royal family when she was only twelve years old. She lived a tragic life because she witnessed the deaths of her husband, her brother, her parents and her son. Because of this, she has been represented as a symbol of tragedy, and this has made her autobiography more special. As a noblewoman, she expressed 恨 (Han) which is deep resentment and sorrow (Kim 2009; my translation). She closely depicted her own family and the royal family. In terms of historical values, she was able to find out about the royal family and incidents, in which it was involved very closely from her own perspective. In her record, individual psychology and affairs of state, personal relations and public duties, innocence and experience, tragedy and mystery are woven together to represent her life, her family and the historical Imo Incident (Wells 2015: 112). This is one of the points, which makes her autobiography so significant (Kim 2005; my translation).

Another significant feature of this autobiography is that it is unusually a female autobiography written in the eighteenth centuries during the Joseon dynasty. Most traditional Korean women writers or artists of that period are unknown or anonymous because it was very difficult for women to get their work published. Only a few women were successfully in being named for their creative work. Most of the surviving works by women were written by noblewomen; they were educated and had enough time to concentrate on producing their creative work, unlike women who belonged to a lower class because they were kept busy working in their homes. Additionally, even though some lower-class women did create some works of literature and art, these have been considered as less important than works created by noblewomen (Kim-Renaud 2004: 4).

This female literature has been translated into different languages, especially into English. There have been three different English translations of Hanjungnok: the first was translated by Grant and Kim (1980), the second by Choe-Wall (1985) and the third by Kim-Haboush (1996). The most recent translation, that of Kim- 
Haboush, has been evaluated as the most successful and progressive one, compared with the previous two in terms of faithfulness to the original contexts and readability for audiences in English. As Hanjungnok is a classical and traditional Korean literary work, it contains stories and customs, which are unusual to audiences from other cultural backgrounds. Kim-Haboush considered both intralinguistic factors, such as idioms, puns and word play, and extralinguistic elements, such as social structure, in her translation. She used simple language and omitted the use of polite language since English puts less linguistic distinction on polite and respectful phrases compared with Korean. Also, the societal system and customs are more carefully explained in her translation (Kim 2009; my translation).

As Drabble was influenced by Kim-Haboush's English translation of Hanjungnok, the use of language in the translation could have affected her novel as well as it can be found that she might have reproduced the voice of Hyegyeonggung Hongssi from the perspective of her Westernised analysis. Also, she has stated that she had attempted to write a universal work, in which the story could be understood and sympathised with by readers from any culture (Drabble 2004). Sapir and Whorf linked linguistic categories to conceptual categories. They argued that linguistic effects go beyond consciousness as language is a prototype of historical ideas (Gumperz and Levinson 1996a: 5). For this reason, accurate translation might be impossible from one language to another because linguistic and cultural differences reflect the world view (Kelly 1979). A novel might include some effects of literature such as over-generalisation or metaphors to increase the fun, in order to attract readers. However, this could also be observed as showing how an author has interpreted and analysed the original autobiography from her own perspective.

This paper will offer a discussion of how cultural perception can be embedded in language and literature using a comparison between a work of classical Korean literature, Hanjungnok, an English-translated version of it, and a work of British literature, The Red Queen, which was inspired by Hanjungnok and which borrowed its story. First, there will be a discussion of how the language usage in each version changed from a Korean autobiography into an English translation of it and then from the translation to the English novel. This will be followed by an exploration of how the autobiography is reproduced in the novel in terms of the author's, from 
Kyu Hyun PARK: Cross-Cultural Literature and Cultural ...

Hyegyeonggung Hongssi's to Drabble's, perspective on family relationships and on gender.

\section{Transmission of the Voice of Hyegyeonggung Hongssi}

\subsection{Original Text to Translation}

It might be difficult to realise the originality of Hanjungnok. It was composed and written in Korean, which makes it immediately distinctive compared with other works written in the same period because works written by men before the modern era were written in literary Chinese (Kim-Haboush 1996: 3). Also, from old Korean to contemporary Korean, there have been several editions and translations. The Hanjungnok edited by Jeong in 2010 has been considered as the most similar to the original Hanjungnok written by Hyegyeonggung Hongssi in the eighteenth century because Jeong included both Old and Modern Korean in the book (Heo 2010; my translation). Hanjungnok, which is called the 'original text', would also have once been translated from ancient Korean into contemporary Korean. There may have been differences in language use and characters between the two, although they are the same Korean. In the same way that the works of Chaucer were written in English, but modern readers nevertheless need a translated version. However, in terms of language transfer, only translation from Korean to English will be considered in this paper.

Both the 2010 edition of Hanjungnok and the translation of The Memoirs of Lady Hyegyong preserve the format of an autobiography. The only difference between the two versions is the language: Korean and English. The major difference between Korean and English is that the former has stronger polite and respectful forms, which have to be strictly followed depending on the hierarchy of communicators, compared with the latter (Song 2014). Kim (2009) made a comparison of the texts between Hanjungnok and The Memoirs of Lady Hyegyŏng in translation studies and found several major points of comparison. The first is the use of metaphors, which would be familiar to readers in the translated language, English. 
(In this paper, I will include 'my translation' as I literally translate the Korean version of Hanjungnok into English, to reduce a translator's or author's choice of language/contextual expressions.)

For instance,

“정처가 비록 인물이 괴이하여 천태만상이나 실은 한 부녀라,
궐내에서 상없는 짓이나 하지 후겸 곧 아니면 조정에 간섭하여
권쓸 의사야 어찌 내었으리오. (Jeong 2002: 128; cited in Kim 2009:
$60-61$ )

'Jeongcheo is a weird person and behaves in various ways, but she is still a daughter as well as a mother. She does things, which are unacceptable in a palace, but it would be impossible for her to meddle in the affairs of the palace and to wield power without thinking about Hugyeom.' (my translation)

\begin{abstract}
'Although Madame [Jeongcheo] was wicked and as changeable as a chameleon, she was still but a woman. Had it not been for [Hugyeom], she would have remained content to meddle in the affairs of the inner palace, thinking it impossible to interfere in the politics of the court and to wield power.' (Kim-Haboush 1996: 153; cited in Kim 2009: 60-61; my translation)
\end{abstract}

In her description 정처 (Jeongcheo), Hyegyeonggung Hongssi used the word 천태만상 (千態萬象), which means something, which has various forms. However, Kim-Haboush translated this into a metaphor of a chameleon. In the eighteenth century, chameleons were not known in the Joseon dynasty, but the translator nevertheless used this expression because it is familiar to readers in the translation target culture (Kim 2009: 60-61). Kim-Haboush considered other cultural factors when translating the source text Hanjungnok in Korean into English. One was cultural differences. The term 옹주 (呩主; Ongju) means a daughter of a royal concubine. This is different from a princess. Only a daughter of queen, who is a consort of a king or crown prince, could be called 공주 (公主; Gongju), a princess. Unlike Korean, English does not distinguish any difference between these words so the translator chose to refer to all royal daughters as princesses (Aixela 1996).

Also, in terms of language use, there are some differences between Korean and English, and they have to be modified as part of a translator's job. Korean has more diverse levels of speech with 
honorifics and polite and respectful expressions than English. In Korean discourse, politeness in language use is related to the relationship between communicators, such as familiarity or social or familial hierarchies, and these might be difficult to understand or distinguish for speakers of English (Song 2012: 140). For example, there are two different ways to describe 'tears' in Korean: 눈물 (nunmul) and 안수 (ansu). The use of each word is different, depending on who is producing the tears and who is describing the act. The first word is commonly used, but the second is related to court language and is used to describe the tears of higherranking people. Even in contemporary Korean, it is used to refer to holy people weeping, such as God or Jesus. In her English translation, Kim-Haboush used only 'tears', regardless of who was weeping. Hyegyeonggung Hongssi, however, used the second form, ansu, when describing the tears of the queen or of her husband, the crown prince Sado Seja and her son because they were of higher rank than Hyegyeonggung Hongssi herself (Kim 2009: 65). In terms of discourse, the English translation of Hanjungnok may have limits in terms of translating discourse or nuance. Hanjungnok is a novel, which reveals Hyegyeonggung Hongssi's emotions towards the people surrounding her in the royal family and in her own family as it is an autobiography. She described 화평옹주 (Hwapyeongongju) using positive language expressions and referred to her as 당신 (dangsin; 'you'), so it can be assumed that Hyegyeonggung Hongssi was offended by Hwapyeongongju) because she referred to her as 그 사람 (geu saram; 'that person'); 당신 becomes simply 'you' in English, but in Korean this expression includes respect and politeness. Kim-Haboush decided to translate both expressions, translating them simply as 'she' or by using the person's name. This device may not fully deliver the emotions of Hyegyeonggung Hongssi but only transfer the actual facts, of what happened. Additionally, Kim (2009: 67) pointed out a distinction between the use of direct and indirect speech. As a work of court literature, in Hanjungnok, Hyegyeonggung Hongssi, as a noblewoman belonging to the royal family, found it difficult to express her feelings directly. Furthermore, one of the beauties of court literature in classical Korean works from the Joseon Dynasty was the use of indirect speech, including metaphors and special expressions, which was used by noblemen and women in ancient times (Kim 2005: 173). 


\section{IJKHSS 4/2018}

For example,

“추동간은 가례하오신 후 성심이 자연 한가치 못 하오셔 [...]”(Jeong 2002: 275)

'After marriage, in autumn and winter, my mind was not naturally free [...]' (my translation)

'His Majesty was preoccupied with his private life, as was natural for a newly married man.' (Kim-Haboush 1996: 293)

Most of the time, Korean does not necessarily contain a subject or agent in language, whereas English does. This is one difference in that the absence of a subject might give the effect of indirect speech. Also, in the example given above, Kim-Haboush directly described the acts of His Majesty, Sado Seja, when he was concentrating on his personal life, unlike the Korean version which indirectly states this as that his 'mind' was not free. This indirectly states that Sado Seja's enjoyment, now that it was not concerned with public affairs such as his responsibilities or duties as a crown prince, would result from the fact that his mind was not on his personal status.

The disparity between Hanjungnok in Korean and in English may create a different image of Hyegyeonggung Hongssi and lead to a different analysis or acceptance of her autobiography.

\subsection{Translated Autobiography to Novel}

Translation can be seen as a reproduction as it is a progress of rewriting original texts. The novel the Red Queen could be the final reproduction of the representation derived from translation. It also keeps the format of an autobiography, because Drabble also wrote her book using Hyegyeonggung Hongssi's narration and her descriptions of her life and of historical incidents, as she saw them. Although the format of the original text persists in each reproduction, the representation of each text cannot be completely the same as each has a different target audience and cultural norm.

Although Hanjungnok and The Red Queen belong to different literary forms because the former is an autobiography and the latter 
is a novel, both depict the same Korean historical events and the activities of the royal family in that period. The literature genres are definitely different but there is also a similarity in terms of literature. An autobiography is more based on fact and reality whereas a novel is largely based on imagination. But if an autobiography is regarded as the representation of the life of the author, a novel can also represent that life to some extent by using real-life characters. Although the characters in a novel are fictional and their lives do not directly interconnect with the author's life, they might nevertheless reflect aspects of the author's personality or values in some respects since the author is a creator as well as a composer in producing and writing stories (De Man 1979: 920). In this sense, the dichotomy between autobiography and novel becomes blurred because a fictional novel can still remain based both on roots of reality and on the author's identity. So, it seems that a novel is a representation, which borrows fictional characters to express the author's inner world. French intellectuals have also stated that it is no longer possible to say with confidence whether an autobiography can be distinguished from a novel in terms of the question of the truth. Rousseau (1941) stated that a narrator in an autobiography has an unreliable memory so an autobiography shows an accurate representation of a narrator's inner feelings rather than a genuinely factual representation. Telling a life story is a product of constructed and remembered narratives. So, both fiction and history are products of human inventiveness and in this context fiction itself forms everyday life and history functions in precisely the same way.

The distinction between autobiography and novel is determined by the way a work of literature is read and this can influence the "plausibility of [an author's] identity as writer" (Frame 1989: 156). This means that this kind of distinction would influence readers in their perceptions towards a work of literature. Depending on the type of the literature, readers can change their attitude towards it. However, it has been debated whether an autobiography contains complicated fuzzy boundaries between factual and fictional discourses. Marcus (1994: 3), cited in Anderson (2001: 2), argued that the intention is a significant point of discussion when considering an autobiography. Both author and readers have existing knowledge and are prepared to reflect their own world-view into understanding texts through literature. The effort of reading an autobiography captures 
their understanding and its context can be differentiated depending on the reader's approach to it.

Margaret Drabble is the author of the novel version of Hanjungnok but she was previously also an audience of the translated Hanjungnok. The audience of the original Hanjungnok did not comprise normal readers because three chapters, written in 1801, 1802 and 1805, were written for her grandson, Sunjo, the twenty-third king of the Joseon dynasty, to inform him about the Imo incident and the breakdown of her family, and one chapter, written in 1795, was for her nephew Hong Suyeong to look back on her life (Kim 2009: 56). Whether Hyegyeonggung Hongssi actually wrote the autobiography as a defense of her family has been a matter of discussion, especially of her father and brothers, who were rumored to be connected with Sado Seja's death and that her family had organized the Imo Incident and set up Sado Seja to be executed by the king. Comparing The Memoirs of 1795, others have been seen as having political aims and Hyegyeonggung Hongssi was demonstrating her family's innocence and protecting them from being attacked by the Kim family (Cho 2000: 6-7). As Drabble was not the target audience of the original Hanjungnok, she could reflect her existing knowledge and world-view into understanding the original context.

It would be true to say that the period, in which Hyegyeonggung Hongssi lived was not a time when women could freely express their opinions or show their values towards the world and society, and her father and father-in-law emphasised that a woman's behaviour as a wife was that a woman should respect her husband and keep silent. This might be true of the idealised woman in that period (Kim 2009: 345), but this could not be the reason why Hyegyeonggung Hongssi wrote Hanjungnok. Choi (1999: 126-127) argued that for Hyegyeonggung Hongssi, writing her autobiography could be seen as an only means of escape and an opportunity for her to communicate with the wider world to talk about her story because, compared with men, women had fewer opportunities to share their writing in public. For this reason, women's writing could be focused on a confession or mental experiences or familiarity between herself and a particular incident. The language use would show self-excuse, confession of a secret, suspicious incidents, or revealing the facts behind stories. The important point is that Hyegyeonggung Hongssi's writing has been evaluated as a means of escape from the limited social conditions, which constrained her and to reflect her family 
background and her political status, and not as a resolution for her female position in a patriarchal society. However, a study of Western female autobiography explains that the main purpose for a Korean woman to write an autobiography was to express women's marginalization as a minority in a masculine society and to explain her position and the constraints which are imposed under patriarchy (Smith et al. 1998). Western female autobiographies have focused on the confirmation of the writer's existence as a woman and as a part of society.

Drabble also seems to have found the female power and voice, breaking a silence as a woman in a masculine society by drawing on Hyegyeonggung Hongssi's autobiography.

'I was occasionally ill, and surely had a right to take to my chamber from time to time, but in truth when young I had a remarkably strong and resilient physical constitution: how else, after so stressful a life, could I have lived so long and seen so much? It was only at the time of the great crisis of the Imo Incident that I succumbed, for a while, and even then, I did not wholly surrender.' (Drabble 2004: 58)

Drabble describes Hyegyeonggung Hongssi as such a strong woman, which could be a personal impression of Hyegyeonggung Hongssi from Drabble's own perspective. In consequence, she depicts the image of Hyegyeonggung Hongssi as a strong woman in any difficult situation, such as her son's or husband's deaths, in her novel. However, in the Korean text, Hyegyeonggung Hongssi may not be revealing her strength, but her weakness.

“세상에 누가 어미와 자식이 없으리오마는, 나와 정조 같은 사이는 다시없으니, 정조가 아니면 내 어찌 오늘날이 있으며, 내 없으면 정조께서 어찌 보전하여 계셨으리오. 모자 둘이 겨우겨우 의지하여 온갖 변고를 다 겪고, [...]모진 목숨이 썩 끊어지지 않아 지금까지 구차히 살아가니, 세상에 나같이 어리석고 나약한 사람이 어디 있으리오.”(Hyegyeonggung Hongssi 2010: 297-298)

'Who does not have a mother and child in the world, but no relationship would be the same as mine with Jeongjo. Without Jeongjo, how would I exist today, and without me, how would Jeongjo survive. We have depended on each other and struggled together [...] this miserable life is not easily finished, so this life keeps on pathetically; who else is stupid and weak like me in the world?' (my translation) 
“목숨을 마치고자 하는 생각이 이번 뿐이 아니라. 정조가 계실 때도 슬프고 화가 날 때면 매양 이 생각을 했으니, 만사를 다 정조를 믿고 참고 지냈더라. 지금은 정조마저 아니 계시니 내 슬픔과 설움이 하늘을 찌를 듯하여 죽을 곳을 얻고자 하는 차에 [...]어이 일시라도 살고 싶은 마음이 있으리오." (Hyegyeonggung Hongssi 2010: 415)

'This was not the only time I have thought about committing suicide, but even when Jeongjo was alive, I thought of it every time I was sad and upset, but I suffered and overcame this by trusting Jeongjo. Now that Jeongjo has passed away, my grief and sorrow have piled up enough to reach the sky, so I try to die [...] how could I wish to live longer?' (my translation)

In this comparison, Drabble portrays Hyegyeonggung Hongssi as a person, who does not easily surrender but who was overtaken by her tragic environment. However, in the Korean text, it is possible to see that Hyegyeonggung Hongssi actually recorded her resentment and sorrow and desired to commit suicide due to her severe and tragic environment after suffering the deaths of her husband, her father, her brothers and her son. Park (2012) argued that Drabble described Hyegyeonggung Hongssi as someone, who has strong self-esteem regarding her desires and who does not lose herself even after enduring chaotic incidents. Drabble re-represented and reproduced Hyegyeonggung Hongssi as a clever and strong woman in her novel. This may be the result of Drabble's perception being reflected in and influenced by her position as a Western woman, so that in her consciousness, she analysed the classical female Korean autobiography as a Western female autobiography because it had the purpose of speaking out to break the silence and to show female resistance to patriarchal social structures.

\section{Reproduction from Hanjungnok to The Red Queen}

As Drabble seems to see Hyegyeonggung Hongssi through Western eyes, she may also analyse other historical incidents in Hanjungnok from her Western perspective. Consequently, she reflected her view and reproduced and represented Hyegyeonggung Hongssi's life and Hanjungnok in her novel. Drabble uses many metaphors 
and compares Hyegyeonggung Hongssi's story and the historical events described in her writing with Western histories and people. For example, Drabble described the Imo Incident, when his father the king Yeongjo ordered Sado Seja to be imprisoned in a rice chest and Sado Seja died there, as a barbarian history before the Enlightenment in the West: "talking about the Enlightenment in the West and talking about past barbarian histories to compare the Imo Incident to Louise XVI of France and Marie Antoinette, [or] the unfortunate wives of Henry VIII" (Drabble 2004: 106-107). Furthermore, Drabble (ibid.: 136) described this incident as depicting the killing of a son just as Queen Agave in theBacchae murdered her son Pentheus and as Peter the Great of Russia murdered his son Aleksei in July 1718. This may imply that Drabble had read and understood Hanjungnok from her Western perspective.

\subsection{Reproducing the Perception of Family Relations}

Drabble, cited in Lee and Drabble (2007: 482-483), stated that she first thought about the Oedipus story after she had read KimHaboush's English translation of Hanjungnok because she read about Hyegyeonggung Hongssi's psychological insights from Hyegyeonggung Hongssi's own narration and the conversations between her and her husband and his father. As a result, Drabble focused on the Oedipus complex and drew on it to illustrate the relationship between king Yeongjo and the crown prince Sado Seja in her novel. The Oedipus complex is the classic Freudian notion regarding the "formation of the ego and of gendered subjectivity". Initially a child sees him or herself as a mother, and this creates the desire to possess a mother. Boys see the symbolic power of the father as a phallus. The desire for a mother is threatened by punishment in the form of castration. As a result, boys decide to change their identification from mother to father and to take a masculine and heterosexual position as a desirable subject form. This implies that father and son are in a rival relationship to possess the mother (Barker 2012: 23). However, there might be diversions from the original text, regardless of the fact that it is an artificially created novel, because as an English woman, Drabble may not have 
considered the Korean tradition and Confucian influence. Parsons (2010) questioned whether this triangular relationship between father, mother and son, which form the Oedipus complex could be universally applicable. It would be universal in terms of having a father, mother and son as a family unit, but the Oedipus complex is the consequence of patterned social structures, especially obvious in a specific patriarchal culture. The level of patriarchy would vary to some degree from one particular culture to another since it is not a fixed standard. Also, Yeongjo and Sado Seja were situated in a specific setting, leading a kingdom which followed Confucianism and as members of the traditional Korean royal family. An understanding of these backgrounds may be necessary in order to understand Hanjungnok properly.

'Perhaps from Sado's birth onwards the king saw my husband as a rival, as a potential parricide. Necessary though that birth was for the survival of the dynasty, maybe he resented it. All fathers find a rival in a son. Maybe that is why we talk so much of filial piety, in an effort to restrain our natural impulses towards parent-murder.' (Drabble 2004: 19)

'Do I believe that Prince Sado intended to murder his father? No, I do not. I think this intention was pinned on him later as an excuse for the father killing the son. But I do think that there were some at court who would have followed Prince Sado rather than his father, mad though Sado was, had it come to open conflict, open choice. He had his followers.' (ibid.: 123)

From these two excerpts, it is possible to see that Drabble depicted the relationship between Yeongjo and Sado as one of rivalry. Because Sado had his followers that could make Yeongjo feel threatened. Yeongjo, as a father, considered his son as a rival so he devised a way to get rid of him. Yeongjo even said that he wished that his son had died instead of his beloved daughter, who died from measles in Drabble's novel.

'But the birth of [Jeongjo] did not reconcile Prince Sado and his father, as I had hoped and expected. After the measles epidemic, things grew even worse between them. I have often heard His Majesty say that it would have been better if Sado had died of the measles. He wished his own son dead. What cruelties there are in words! These words had a truth in them, but they should never have been spoken.' (ibid.: 53) 
The text in Drabble's novel indicates that king Yeongjo thought of his son as a rival so seriously that his desire to get rid of his son was obvious. However, in the Korean text,

" 1752 년 10 월에 홍역이 크게 번져 화협옹주가 먼저 않으니, [...] 날이 얼마 지나지 않아 경모궁께서도 붉은 반점을 보이며 홍역에 걸리셨는데 경모궁께서 끝내실 즈음에 내가 또 걸리고 원손도 않으시니, [...]경모궁께서는 홍역을 보낸 후에도 여열이 굉장하시니, 그때 아버지께서 경모궁도 뵙고 나도 구호하고 원손도 보호하려 밤낮으로 세 곳을 다니셨는데, 애태우며 근심하시어 머리가 하얗게 세어 계시더라. 화협옹주는 그 병 끝에 상사가 나니라. 경모궁께서 그 누님의 처지가 당신과 같으심을 불쌍히 여기셔서 우애가 자별하시더니, 옹주 병환 중에는 아랫것들을 계속 보내 안부를 물으시고, 상사 난 후에는 애통을 이기지 못하시더라. 이런 일로 보아도 타고난 천성이 착하심을 가히 알지라.”(Hyegyeonggung Hongssi 2010: 50-51)

'In October, 1752, the measles epidemic spread and Hwahyeop Ongju was ill with this first, [...] a few days after, Sado Seja also had it with red spots on his body, and after he was recovering from this, I had measles and my son got it, [...] My father was worried about this illness so he came around to visit Sado Seja, me and my son to take care of us. My father was very concerned about this, so that his hair had become whiter. Hwahyeop Ongju finally passed away with measles. Sado Seja mourned a lot because of their close relationship, and he could not bear this. From this, it is possible to know that his nature is kind.' (my translation)

When the measles epidemic was recorded in the Korean Hanjungnok, it was difficult to discover what was in Yeongjo's mind, as Drabble stated:

'As soon as the Crown Prince [Sado Seja] improved a bit, I came down with the illness. [...] On the same day, the present King [Jeongjo] came down with red spots all over his body. [...] But Father was greatly burdened now that he had several people to tend to and nurse. Shuttling back and forth day and night for an extended period between his daughter and his grandson, he must have reached a state of total exhaustion.' (Kim-Haboush 1996: 76)

'Princess Hwahyeop died of measles. Prince Sado had always been particularly affectionate toward her. He felt sympathetic that she, like himself, was disfavoured by His Majesty. During her illness, he sent one servant after another to inquire after her. When she died, he was 
overcome with grief. This shows that he was truly kind-hearted by nature.' (ibid.: 263)

The translation by Kim-Haboush also describes the measles epidemic, but it only states the disease was caught by Sado Seja, Hyegyeonggung Hongssi and Jeongjo, and that Hwahyeop Ongju died of it. Drabble might have added what she imagined was in Yeongjo's mind as she analysed the autobiography on the basis of Freudian psychoanalysis. As a father, Yeongjo's desire to kill his son could have been developed from the Oedipal notion: a father recognises his son as a rival, so he wishes to kill his rival, and a son has a fear of being castrated by his rival father. For both father and son, one should get rid of his rival quickly before being killed himself (Johnson and Price-Williams 1996). It has been stated that the first stages of an Oedipal situation can bring anxiety, pain and guilt. The depressed state and the Oedipus complex are interlinked so the resolution of this conflict has to be shaped by oral, anal and sadistic acts and by hatred and fear towards parents (Etchegoyen 2002: 23). Sadism in the perspective of Freudian psychoanalysis seems a naturally developing feeling and desire for both father and son.

In Drabble's novel, Hyegyeonggung Hongssi assumes that Yeongjo was affected by sadism.

'There was one day a dreadful scene about a jade helmet that Prince
Sado was supposed to wear for some tedious and unpleasant
ceremonial occasion - I think it may have been an interrogation
or an execution. I should mention that Sado's sadistic father never
allowed him to undertake any pleasant official or ceremonial duties,
such as attending archery contests or graduation parties, but insisted
instead that he assist at various unpleasant public events at the Board of
Punishment. He seemed to take a particular pleasure in summoning
Sado to these events in winter, when it was snowing. (There were
always conspiracy trials in progress in our country: we lived in a
culture of denunciation and counter denunciation.) [...] His father
mocked and sneered and shouted, and Sado grew defiant, and flung the
helmet to the earth, with some stream of sad nonsense relating to his ill
fortune and the powers of the accursed jade, and the gods know what
demented rhetoric.' (Drabble 2004: 76-77)

Hyegyeonggung Hongssi, in the voice of Drabble's novel, narrates how Sado's father Yeongjo was so sadistic so that he handed over cases and court work regarding punishment and execution to Sado 
Seja. This also links to Sado's own brutal and cruel behaviour, because he had become familiar with executions due to his environment.

“영조께서는 여러 사건 가운데 의금부나 형조에서 담당한 사형죄는 친히 살피지 않으시고, 옹주들 처소에 계실 제는 내관에게 맡기시니라. 1749 년 정월 경모궁께 대리청정을 시키실 때, 1748 년 6 월 화평옹주 상사 후 슬픔도 심하시고 병환도 잦으셔서 휴양하시겠노라고 대리청정령의 이유를 밝히셨으니, 실은 꺼림칙해서 안에 들이기 싫은 사건을 내관에게 맡기기도 답답해서 다 동궁께 맡기고자 하신 뜻이라.” (Hyegyeonggung Hongssi 2010: 41-46)

'Yeongjo did not carry out death penalties sentenced by the State Tribunal or the Board of Punishment, but made subordinates do so while he stayed in his princesses' house. When Yeongjo gave Sado Seja a role as his deputy, the death of Hwapyeong Ongju had happened in June 1748, so he was still in mourning and his health was not good so he wanted Sado Seja to become his deputy so that he himself could take a rest. However, Yeongjo did not want to handle weird cases, and he did not fully trust his subordinates, so he handed over his work to Sado Seja.' (my translation)

The Korean text records the reason why Yeongjo handed over his job, which included his intention to take a rest and probably to see how the crown prince would develop his way of ruling in the future.

'His Majesty was truly outstanding among rulers in history. [...] However, His Majesty experienced too many harrowing events: the purges and intrigues of the simin years (1721-1722) and the musin (1728) rebellion, to name just two. In the course of these events, he adopted numerous taboos and a peculiar gravity that were severe enough to be considered a sickness. [...] His Majesty often asked Prince Sado to attend the trials of political criminals, trials at the Board of Punishment, or trials that required personal interrogation by the king. These events, to which the Prince was invited were all grim and inauspicious affairs. [...] His Majesty had an aversion to criminal cases, especially trials for murder or other serious crimes conducted at the State Tribunal or the Board of Punishment. He often sent eunuchs with instructions while he remained at the residence of one or another of the princesses. The edict enacting the regency cited his reasons as grief over Princess Hwapyeong's death, his ill health, and the need for a rest, but His Majesty's true intention was to let the Prince-Regent take care of those cases that he detested but were too serious for eunuchs.' (Kim-Haboush 2010: 256-258) 
Kim-Haboush's English translation also describes the reason for the regency of Sado Seja on behalf of the king in the same way as in the Hanjungnok in Korean, as that Yeongjo had experienced a difficult time over his daughter's death and several other incidents. This seems to accord with the view of seeing the world in literature and analysing it in a way, which might be reflected by a reader's value and belonging in a particular environment or culture. Whorf insisted on the interrelationship between language, culture and consciousness. In the Sapir-Whorf hypothesis, Whorf and Sapir argued that culture can construct the consciousness and world-view of a speaker and these can then be displayed in language (Subbiondon 2005: 151). According to Sapir (1970: 207), language does not exist apart from culture, but comes from the "socially inherited assemblage of practices and beliefs", which determine the nature of a speaker's life and society. This is because people express their values using their language. Whorf stated that consciousness tends to be determined culturally, not genetically (Subbiondon 2005: 152). Once Drabble decided to analyse the relationship between Yeongjo and Sado Seja as Oedipal rivals, she went on to analyse all the intentions of both Yeongjo and Sado in terms of Freudian psychoanalysis. Linguistic Relativity is processed in the following logic: (1) differences exist in linguistic categories across language; (2) linguistic categories are able to determine individuals' thinking; and (3) aspects of individuals' thinking differs across linguistic cultures or communities depending on the language they use (Gumperz and Levinson 1996b: 24).

Kim-Haboush's book is written in English, but it is a combination of a Korean context and the English language. The source text is in Korean so the translation can convey the Korean context, but as the target language of the translation is English, the use of a different language might construct new perceptions. Also, the audiences of the translated books are foreign (that is, anything but Korean), especially people from English-speaking countries, so they will have a different analysis of the same story just as Drabble does. However, it would be ambiguous to judge that Yeongjo made Sado Seja take over only tasks involving punishment and execution on the basis of writings of Hyegyeonggung Hongssi. Prince-regency was sometimes tried in the Joseon dynasty. If a king was too old or ill, his crown prince could alternatively or temporarily take over the position of king. There were six instances of prince-regency in the Joseon 
dynasty. The aim of a regency was to shift the power in order to give time for a crown prince to prepare to exercise his authority (Cho 2010). Drabble's lack of understanding of traditional Korean customs could explain her diversion from the original story, as she acknowledged that she was not very familiar with traditional Korean culture (Lee \& Drabble 2007), or she could have deliberately omitted this background in order to make the story tenser. This could mean that she had injected her own experienced culture and knowledge into her analysis of Korean literature, and this would be natural for the audiences who are not familiar with this aspect. For English speakers, Western works of literature have very possibly been analysed in the Freudian or Oedipal ways, such as Hamlet or Greek myths, which would make this insight of psychoanalysis possible (Sohn 2008).

Drabble may also have taken the idea of the Oedipus complex from Hyegyeonggung Hongssi's affection for her sons.

\begin{abstract}
'Although the most common of human relations is that of mother and son, the mother/son tie between myself and the late King was like no other. If it had not been for the late King, I would not be here today; had it not been for me, the late King would not have been protected and preserved. Having experienced hundreds of trials and difficulties and having been each other's support through these stormy years, mother and son both awaited a blessed old age when, in retirement, we could enjoy the peace and prosperity of the nation.' (Kim-Haboush 1996: 199)
\end{abstract}

It seems that Hyegyeonggung Hongssi showed affection towards her son but she also shows the attachment between herself and son, and vice versa. This may have given a clue to Drabble because of the relationship with a possessive desire between mother and son. Drabble could see Hyegyeonggung Hongssi as a strong woman, because she seems to have pride in having a son, who became king after his grandfather and she, anyway, could protect her important son.

Drabble depicted King Yeongjo as wanting to kill his son, Sado Seja, because of a feeling of rivalry, but the royal succession for the kingdom was the most important factor in the Joseon dynasty, as Drabble may have recognised.

'This may be the moment at which I should try to explain to you, to posterity, the reason - if one may call it a reason - why Prince Sado had to die in the rice chest, and not in some less painful or more 


\section{IJKHSS 4/2018}

dignified manner. Prince Sado had to die like this because it was very important to the state and to the royal succession that he should not die in the manner of a common criminal.' (Drabble 2004: 131)

"대저 경모궁 돌아가신 일에 대해서는 두 가지 의견이 있노라. 한 의견은 그때 영조께서 내리신 처분이 광명정대하다고 하며, 그 처분을 영조의 거룩하신 큰 업적으로 일컬어 '세상 어디에 내놓아도 당당하고 떳떳하다'고 하는 것이라. 또 다른 의견은 경모궁께서 병환이 없으신데 원통히 그리되셨다 하는 것일. 앞의 의견은 경모궁께서 속에 다른 뜻을 품은 죄가 있기에 영조께서 무슨 역적이나 평정하신 듯이 처분 하신 것으로 본 것이니, [...] 경모궁을 역적으로 보고 정조를 죄인의 아들로 보는 것이니, 이는 경모궁과 정조 두 분 모두에게 망극한 말씀이라. [...] 경모궁께서는 분명히 병환이 있으셨고, 비록 병환 때문이긴 하지만 임금과 나라의 위태로움이 급박한 지경이 되었으니, 영조께서 슬픔은 한이 없지만 어쩔 수 없이 그 처분을 하시니라." (Hyegyeonggung Hongssi 2010: 322)

'There are two opinions on the death of Sado Seja. One is that Yeongjo's decision to put his son in the rice chest was fair so it could be regarded as his great work in the world. Another is that Sado Seja did not have any (mental) disease, but was killed unjustly. The former is that Sado Seja had a hidden intention so Yeongjo treated him as a betrayer, [...] Seeing Sado Seja as a betrayer as well as seeing Jeongjo as a betrayer's son, this opinion is immeasurably impolite. [...] Sado Seja definitely had a disease and simply because of this illness his existence had threatened the King and the kingdom, so Yeongjo necessarily ordered his son to be put in the rice chest although he was in sorrow at having to do this.' (my translation)

'Two opinions have emerged concerning the event of that year [1762]. One is that His Majesty's decision was an impartial and brilliant act of justice. Those who hold this opinion call it the most sagacious and admirable of His Majesty's accomplishments, one in harmony with all of Heaven and Earth. The other opinion is that Prince Sado was not ill but met that tragedy unjustly. Those who hold the former opinion assume the criminality of Prince Sado, that he harboured a truly evil intent. This renders an aura of righteousness to His Majesty's act. It makes it a meritorious deed of the same nature as vanquishing an enemy nation. But what kind of person does this view make of Prince Sado; where does it leave the late King? This view discredits Prince Sado and the late King. The second view, on the other hand, implies that His Majesty took that extreme measure against the Crown Prince on the basis of mere slander. This opinion might originate in a wish to console Prince Sado and to restore his honour, but it does so at the expense of His Majesty's virtue.' (Kim-Haboush 1996: 216) 
Sado Seja went to some trouble to kill people and was obsessed with wearing strange clothes and was afraid of thunder. He is even recorded as mingling with lower-class people to have fun and also sexually abusing some women. This was a problem for Yeongjo because at that time Sado Seja was his only son who could succeed to the Royal throne because there were other families, who were not related to the Yi family (as the Joseon dynasty was the Yi family dynasty), who could threaten the Yi family and seize the throne. The dilemma was also that there had to be a justification for Yeongjo to kill his son; under the law of that time, they did not kill mad people, so if Sado was mad, the King would become a horrible father. Also, if Sado was not mad, then the reason for his death would have to be that he was betraying his father, the King. But this would mean that Jeongjo, the son of Sado, also could not succeed to the throne, because he would be a son of a criminal (Lee 2014). This is all bound up in the cultural knowledge regarding the Confucian royal family in a particularly Korean tradition. Audiences in Korea may have assimilated this easily, but readers from other countries may not see this as a justification, because it is an immoral idea to kill a son, and would be against the rational enlightenment from the Western perspective. Comparing the Korean version and the English translated version, the message would be similar, but the language use seems different. Kim-Haboush directly used the word 'tragedy', unlike the Korean version which just expresses the grief of the situation and of King Yeongjo, who had to decide over his son's life and death. Also, the word 'vanquishing' in Kim-Haboush's translation gives a strong impression regarding Sado Seja. Drabble might have had the idea from this use of strong masculine words of this kind that Sado truly did seem to be a serious rival or even an enemy to the king and his authority.

\subsection{Reproducing the Understanding of Gender}

As Drabble (re)wrote the novel, a female autobiography is revealed as a way to express the oppression of women in a masculine and patriarchal society from a woman's point of view (Smith \& Watson 1998). Drabble may also have recognised and analysed 
Hyegyeonggung Hongssi and her autobiography in this way. However, Hyegyeonggung Hongssi represented her painful feelings by using some direct language (Kim 2005: 170), such as describing how her several attempts at suicide represented the oppression, which she endured from the social structure.

\begin{abstract}
'My mother told me my duty, and told me that it would be fulfilled if I were to submit silently to the act, and to continue to respect my husband. My mother respected my father. I have witnessed this. I knew my duty. It was my duty to conceive and to bear an heir. The act of sex seems to give pleasure to most men, and they seek it, sometimes to their peril. My father-in-law the king had more than one wife: this was his duty. [...] Maybe it [intercourse] pleases some women of other social orders, or in other lands. But for me, the act was so bound, so circumscribed, by such a deadly importance. It was like an examination - like those examinations, over which my father and my brother slaved so diligently in the search for advancement and enlightenment. I passed.' (Drabble 2004: 40)
\end{abstract}

In the novel, Drabble describes the duty of a woman and a wife. She shows how the social gendered role was based on a biological difference. This difference dictated women's duty to keep silent and to obey their husband. The translation of Kim-Haboush also shows a similar content.

\footnotetext{
'Because of my extreme youth when I had my first child, I did not do well in my maternal duty.' (Kim-Haboush 1996: 74)

'Later, His Majesty reproached me. "You just follow your husband's wishes. You don't even become jealous as other women do". This was the first time that I had been reprimanded since my marriage in kapcha [year] (1744), and I was deeply mortified. it is ironic. A women's jealousy is one of the seven heinous crimes [which are deadly sins], and not being jealous of one's husband's interest in other women is considered a great feminine virtue, yet I was being criticised for not being jealous.' (ibid.: 266-267)
}

Drabble may have been inspired to write this paragraph by some parts of Kim-Haboush's translation. The first extract from Kim-Haboush's translation describes Hyegyeonggung Hongssi's maternal duty as she lost her first baby, and it was her duty to give birth to a son for the royal family as the wife of the crown prince. Both Drabble's and KimHaboush's versions contain the injunction about women's silence 
and duty for their husband. The voice may be similar but the approach to this content is different between the two. Western intellectuals significantly address the subjectivity and the representation of women. Kristeva (1980) emphasised that women are situated in the representation of silence, absence, lack or hysteria. Drabble may have adapted this idea to analyse Hyegyeonggung Hongssi as a woman. Gender studies in Western countries have focused on recognising women's existence and their minority role in a masculine and patriarchal society. Drabble may have seen Hyegyeonggung Hongssi as a strong woman who could speak out against patriarchy because in the extract from Kim-Haboush's translation, Hyegyeonggung Hongssi was scolded by the king because she did not even feel jealous about her husband's affairs with other women, and she questioned the king's attitude to jealousy and its irony in terms of the teachings of Confucianism. From Drabble's perspective, Hyegyeonggung Hongssi was a loyal woman, who adhered to the Confucian precepts as her duty, because Confucianism contains the hierarchical doctrines of the 'Five Relationships' and the 'Three Bonds.' The five relationships refer to affection between father and son; duty between ruler and subject; distinction between husband and wife; precedence of the old over the young; and trust between friends. The three bonds confirm the hierarchy of authority: the ruler over minister; father over son; and husband over wife (Li 2000: 14). This ideology includes the notions of 男尊女卑, namjon yobi ('men should be respected whilst women are belittled') and 男女有別, namnyo yubyul ('men and women are in different positions'), which requires obedience by women to their father, husband and son (Choi 2009: 14, [in] Park 2016: 4).

It does not seem that Hyegyeonggung Hongssi blamed Confucianism or its strictness regarding gender-bias, but she seems to have felt that she had been falsely accused because she kept to the Confucian rules, but the king blamed her nevertheless. However, for Drabble, the matter of women's silence became obeying men and being objectified by men: women are seen as men's object, especially a sexual object. She may have thought that during intercourse, women are under men, and this also represents a woman's social status. For women living in a patriarchal society, men's rule is symbolised as a sexual conquest as well.

Yeongjo gave Hyegyeonggung Hongssi another duty. 


\section{IJKHSS 4/2018}

'Never, he [King Yeongjo] said to me when I was yet a child, a prepubertal child, never leave traces of red cosmetic on a white cloth. Keep your linen white. Men do not like to see the red smear, he told me. Do not let men see your artifice. [...] I now think, with the benefit of maturity and an afterlife, and in light of my readings of nineteenth and twentieth-century anthropological and psychological literature, that he was speaking of men's fear of menstrual blood. But did he know that? Did anyone, at that time, know that? I think not. How eagerly we women may watch for the smear of blood. And how, at times, we, too, may fear to see it.' (Drabble 2004: 20)

'Looking at these images through my envoy's modern eyes brought back to me many memories of formal court life, and of the more intimate scene of my defloration. My father-in-law would not have liked the sight of the red blood on the pale sheets of the nuptial bed, although the shedding of this blood signified the conception of an heir.' (ibid.: 28)

“영조께서 $[\cdots]$ “여편네 속옷 바람으로 남편을 뵐 것이
아니니, 세자 보는 데 옷을 함부로 헤쳐 보이지 말고, 여편네
수건에 묻은 연지가 비록 고운 연지라 해도 아릅답지 않으니
묻히지 마라" 하시니라. 내 그 경계를 명심받고, 속옷과
연지 일은 늘 마음에 두어 조심하니라." (Hyekyŏngkung
Hongssi, 2010: 187)

'Yeongjo said [...] "don't show your underwear to your husband, and don't loosen your clothes in front of him, don't leave a stain of rouge on your towel though it is beautiful." I kept this in mind and had always taken care of my underwear and rouge.' (my translation)

'His Majesty came over and said, "Now that I have formally received your gift as your father-in-law, allow me a word of advice. In serving the Crown Prince, please be gentle with him and do not be frivolous of voice or expression. If his eyes wander, pretend that you do not notice. It is not at all an unusual thing in the palace, and so it is best to behave normally, not letting him know that you noticed." He continued, "It is improper for a woman to show her undergarments to her husband. So, do not carelessly loosen your clothes in his presence. There is another thing - the rouge stains on women's towels are not pretty, even though it is rouge. So, do not leave rouge marks on a towel.' (Kim-Haboush 1995: 67-68)

Although Hyegyeonggung Hongssi and Kim-Haboush recorded this happening as Yeongjo's warning about appropriate behaviour for women regarding underwear and rouge, this could also possibly 
lead us to think that Drabble truly accepted Western psychoanalysis in this novel because she stated that Hyegyeonggung Hongssi studied contemporary Western psychoanalysis and assumed that Yeongjo was afraid of the colour red so he prohibited her attitudes regarding this. In Freudian psychoanalysis, there is the connection between 'virginal anxiety" (the "first encounter with the problem of sex") and hysteria in girls. Men avoid deflowering women because of their horror of blood and menstruation, according to Freud (1918). This is because blood and this red colour could link to sadistic fantasies. As a result, common symbols for virginity and defloration in dreams or symptoms are flowers, the breaking of glass, the colour red, blood, and so on. For boys, the anxiety of castration is huge to the extent that they see losing virginity as a form of castration for women, in terms of losing a pure and important part of the body, because both the loss of virginity and castration are unconscious fears for men and women (Erwin 2002: 592-593). This is a cultural element determining how an audience accepts a context depending on the reader's own cultural language and experience.

\section{Conclusion}

This paper discussed how cultural perception can be embedded in language and literature. From the comparison between a work of classical Korean literature, Hanjungnok, and English-translated version of it, and a work of British literature, it could discover that receipt of the literature could be various depending on the belonging culture of the audience. The author of the British novel, The Red Queen, Margaret Drabble was inspired by the translated version of Hanjungnok, and she re-wrote the voice of the protagonist as well as an autobiographer, Hyegyeonggung Hongssi. Hyegyeonggung Hongssi re-states her past life and describes the history that her husband, the crown prince Sado Seja, was killed by the order of his father, King Yeongjo. In the British novel, it illustrates the same Korean historical incident as in Hanjungnok; however, in the novel, it would include the Westernised perception to analyse the incident in its description by Hyegyeonggung Hongssi. 
First, this paper compared the language use between Hanjungnok in Korean and Kim-Haboush's translated one in English. Due to the lack of polite and respectful expressions and discourse in English compared to in Korean, the English-translated version tends to be more straightforward to illustrate people's emotions than the original Korean text, which Hyegyeonggung Hongssi chose indirect speech. To compare the translated version of autobiography and Drabble's novel, it was considerable the distinction between autobiography and novel as a type of literature. Each has a difference: autobiography is the one draws a fact; while, novel is based on fiction. However, it is ambiguous to divide writing between fiction and nonfiction because autobiography also depends on a writer's memory and intention as a novel would do. In this reason, this paper understood that both autobiography and novel would be the reflection of a writer's notion and world-view.

The differently analysed perceptions were featured in illustrating family relations and gender. Both factors were discussed in the original text as well. The relation between the king Yeongjo and his son Sado Seja was the main theme in both texts as Sado Seja ended his life with death ordered by the king. Hyegyeonggung Hongssi originally assumed this as they misunderstood each other because the king expected his son to be a perfect crown prince, who is eligible to succeed his royal throne; but Sado Seja could not follow his expectation but was stressed with this. Drabble analysed this as the classic Freudian psychoanalysis - the Oedipus complex. She put this father and son as rivalry who wants to castrate/kill each other in her Western perspective besides the Confucian or royal tradition of the Joseon dynasty of Korea. Also, Drabble depicted Hyegyeonggung Hongssi as a strong woman, who questioned the gender discrimination and silence of women. However, it seemed that the original Korean text would illustrate as Hyegyeonggung Hongssi adapted the Confucian thinking and gender role as a woman in the past. This may be the combined result with that the Englishtranslation would use strong words and that the British author's Western value is included. From these, it would assume that cultural perception and analysis of literature would be interconnected in the situation, where a reader or writer comes from and belongs to. Furthermore, reproduction of re-writing literature and of representing cases and characters would be reflected by the culture of a writer as literature could be the means of observing a society and its culture. 
In further studies, it would be necessary to explore other factors, such as author's or audience's personality or values, attitudes, or individual culture, which could influence to translation or interpretation of literature, besides language and collective culture.

\section{References}

Aixela, Javier F. 1996. Culture-Specific Items in Translation. [In] Translation, Power, Subversion, ed. Roman Alvarez and M. C. Vidal, 52-78. Clevedon: Multilingual Matters.

Anderson, Linda. 2001. Autobiography. New York: Routledge.

Barker, Chris. 2012. Cultural Studies: Theory and Practice. $4^{\text {th }}$ Edition. London: Sage.

Cho, Mieun 조미은. 2010. 조선시대 왕세자 대리청정기 문서연구 Joseonsidae Wangseja Dericheongjeonggi Munseoyeongu. 고문서연구 Gomunseo Yeongu. 36: 1-13, http://congress.aks.ac.kr/korean/files/2_1393908782.pdf (accessed September 1, 2016).

Cho, Sungsan 조성산. 2000. 혜경궁 홍씨는 왜 '한중록' 을 지었는가? Hyegyeonggung Hongssineun Weo 'Hanjungnok'eul Jioetneunga?. 내일을 여는 역사 Naeileul Yeoneun Yeoksar 3: 5-13, http://www.dbpia.co.kr/Journal/ArticleDetail/NODE00643624 (accessed September 1, 2016).

Choe-Wall, Yang Hi, trans. 1985. Memoirs of a Korean Queen. London: Routledge.

Choi, Hyaeweol. 2009. Gender and Mission Encounters in Korea: New Women, Old Ways. Berkeley: University of California Press.

Choi, Kisook 최기숙. 1994. 자서전, 전기, 역사의 경계와 언술의 정치학 Jaseojeon, Jeongi, Yeoksaui Gyeonggyewa Eonsului Jeongchihak. 여성이론 YeoSeong Iron. 1: 122139,https://www.dbpia.co.kr/Journal/ArticleDetail/NODE013 84357 (accessed February 14, 2016).

De Man, Paul. 1979. Autobiography as De-Facement. Comparative Literature 94(5): 919-930.

Drabble, Margaret. 2004. The Red Queen. London: Penguin Books. 
Erwin, Edward. 2002. The Freud Encyclopedia: Theory, Therapy, and Culture. Ed. New York: Routledge.

Etchegoyen, Alicia. 2002. Psychoanalytic Ideas about Father. [In] The Importance of Fathers: A Psychoanalytic Re-Evaluation, ed. Judith Trowell and Alicia Etchegoyen, 18-40. New York: Brunner-Routledge.

Frame, Janet. 1989. An Autobiography. Auckland: Century Hutchinson.

Freud, Sigmund. 1918. Das Tabu der Virginität (Beiträge zur Psychologie des Liebeslebens, III). Samm-lung kleiner Schriften zur Neurosenlehre 4: 229-251. Leipzig and Vienna: F. Deuticke

Grant, Bruce K. and Chin-man Kim, trans. 1980. Han Joong Nok: Reminiscences in Retirement. New York, NY: Larchwood Publications Limited.

Guardian. 2011. 1000 Novels Everyone Must Read. The Guardian, March 14.

Gumperz, John J. and Stephen C. Levinson. 1996a. Introduction:

Linguistic Relativity Re-Examined. [In] Rethinking Linguistic Relativity, ed. John J. Gumperz and Stephen C. Levinson, 121. Cambridge: Cambridge University Press.

Gumperz, John J. and Stephen C. Levinson. 1996b. Introduction to Part 1. [In] Rethinking Linguistic Relativity, ed. John J. Gumperz and Stephen C. Levinson, 21-36. Cambridge: Cambridge University Press.

$\mathrm{Heo}, \mathrm{Mi}$ Kyeong 허미경. 2010. 문학동네 한국고전문학 전집 나왔다 Munhagdongne Hanguggo jeonmunhagjeonjib Nawatda. The Hankyoreh. August 23.

Hyegyeonggung Hongssi 혜경궁 홍씨. 2010. Hanjungnok 한중록. Ed. Byeongseol Jeong 정병설. Seoul: 문학동네 Munaktongne.

Jeong, Eunim 정은임, trans. 2002. 한중록 Hanjungnok. Seoul: 이회 Yihwe.

Johnson, Allen W. and Douglass Price-Williams. 1996. Oedipus Ubiquitous: The Family Complex in World Folk Literature. Stanford: Stanford University Press.

Kelly, Lewis G. 1979. The True Interpreter. Oxford: Basil Blackwell. Kim Haboush, Jahyun. 2011. The Memoirs of Lady Hyegyŏng. [In] Finding Wisdom in East Asian Classics, ed. Wm. Theodore de Bary, 352-364. New York: Columbia University Press. 
Kyu Hyun PARK: Cross-Cultural Literature and Cultural ...

Kim-Haboush, Jahyun. 1996. The Memoirs of Lady Hyegyŏng: the Autobiographical Writings of a Crown Princess of Eighteenth-Century Korea. Berkeley: University of California Press.

Kim-Renaud, Young-Key. 2004. Introduction. [In] Creative Women of Korea: The Fifteenth Through the Twentieth Centuries, ed. Young-Key Kim-Renaud, 3-25. London: Routledge.

Kim, Young 김영. 2005. 한일 궁중문학의 본질과 미의식의 표출양상 Hanil Gungjungmunhakui Bonjilgwa Miuisigui Pyochulyangsang. 일본문화 연구 Ilbonmunhwa Yeongu. 27: 163-178,

http://www.dbpia.co.kr/Journal/ArticleDetail/NODE01034994 (accessed February 5, 2016).

Kim, Youngshin 김영신. 2009. 번역본 Han Joong Nok Gwa The Memoirs of Lady Hyegyong 비교 연구: 충실성과 가독성을 중심으로 Beonyeokbon Han Joong Nok Gwa The Memoirs of Lady Hyegyong Bigyo Yeongu: Chungsilseonggwa Gadokseongeul Jungsimeuro. 번역학 연구 Beonyeokak Yeongu. 10(3): 53-75.

Kristeva, Julia. 1980. Desire in Language: A Semiotic Approach to Literature and Art. New York: Columbia University Press.

Lee, Deokil 이덕일. 2014. 이덕일의 고금통의 2 Yideokilui Gogeumtonguil 2. Paju: 김영사 Gimyeongsa.

Lee, Young-oak and Margaret Drabble. 2007. An Interview with Margaret Drabble. Contemporary Literature. 48(4): iv-498, http://muse.jhu.edu/article/233041 (accessed February 14, 2016).

Li, Chenyang. 2000. Introduction: Can Confucianism Come to Terms with Feminism? [In] The Sage and the Second Sex: Confucianism, Ethics, and Gender. ed. Chenyang Li, 1-22. Chicago: Open Court.

Marcus, Laura. 1994. Auto/biographical Discourses: Criticism, Theory, Practice. Manchester: Manchester University Press.

Park, Inchan 박인찬. 2012. 동양과 서양사이 Dongyanggwa Seoyang Sai. 새한영어 영문학 Saehanyeongeo Yeongmunhak. 54(1): 39-64, http://book.aks.ac.kr/lib/down2.asp?idx=891 (accessed August 5, 2016). 
Park, Kyu Hyun. 2016. Inhumanity of the Neo-Confucius Son Preference and Gender-Biased Discrimination in South Korea: The Case of the Korean Novel, 'The Dreaming Incubator'. SOAS, University of London, Cultural Studies. Term2 MA assignments. Unpublished.

Parsons, Anne. 2010. Is the Oedipus Complex Universal? [In] Psychological Anthropology: A Reader on Self in Culture. ed. Robert A. Levine, 131-153. Oxford: Wiley-Blackwell.

Rousseau, Jean J. 1941. The Confessions of Jean Jacques Rousseau. London: Reeves and Turner.

Sapir, Edward. 1970. Culture, Language and Personality. Ed, David G. Mandelbaum. Berkeley: University of California Press.

Smith, Sidonie and Julia Watson. 1998. Introduction: Situating Subjectivity in Women's Autobiographical Practice. [In] Women, Autobiography, Theory: A Reader. Ed. Sidonie Smith and Julia Watson, 3-56. Madison: The University of Wisconsin Press.

Sohn, Taesoo 손태수. 2008. 한중록과 붉은 왕세자빈에 나타난 문화횡단성 연구 Hanjungnokgwa Bulgun Wangsejabin ae Natanan Munhwa Heongdanseong Yeongu. 정신 문화 연구 Jeongsin Munhwa Yeongu. 31(1): 243-269, http://www.dbpia.co.kr/Journal/ArticleDetail/NODE01158401 (accessed August 1, 2016).

Song, Sooho. 2012. Politeness and Culture in Second Language Acquisition. New York: Palgrave Macmillan.

Subbiondo, Joseph L. 2005. Benjamin Lee Whorf's Theory of Language, Culture, and Consciousness: A Critique of Western Science. Language and Communication. 25(2): 149-159.

Wells, Ken. M. 2015. Korea: Outline of a Civilisation. Leiden: Brill. 